\title{
Support for Gender Stereotypes: Does Madrasah Education Matter?*
}

\author{
M Niaz Asadullah \\ Department of Development Studies, University of Malaya, Malaysia; \\ Department of Economics, University of Reading, UK; \\ Centre on SKOPE, University of Oxford, UK; \\ IZA Institute of Labor Economics, Bonn, Germany \\ Sajeda Amin \\ Population Council, USA \\ Nazmul Chaudhury \\ World Bank, USA
}

\begin{abstract}
This paper examines the influence of the institutional nature of schools on gender stereotyping by exploring contrasts between non-religious and Islamic faith (i.e. madrasah) schools among secondary school-going adolescents in rural Bangladesh. In particular, differences in gender attitudes across school types are explored to elucidate what about schools matter. Using a uniquely designed survey to assess the influence of school type on student characteristics, we find large differences in stereotypical gender attitudes by school type and student gender. Madrasah students in general, and unrecognized madrasah students in particular, show unfavorable attitudes about women and their abilities compared to their peers in non-religious schools. However, these differences are diminished considerably in ordered probit models suggesting that school-level differences are explained by teacher characteristics such as the nature of teacher training and average family size of teachers. These estimated effects are robust to conditioning on a rich set of family characteristics.
\end{abstract}

JEL classification: I21, Z12, O12, O15.

Key words: Islamic education; gender norms; gender inequality; madrasahs.

\footnotetext{
* M Niaz Asadullah is grateful to the Leverhulme Trust for funding this study as part of a research fellowship (from September 2011 to December 2012) on “The Rise of Islamic Schools in Bangladesh”. An earlier version of the paper benefited from seminar presentations at the University of Reading. We are also grateful to two referees of this journal for valuable comments. While the data used in the paper is not available in public domain, we would be happy to make the data available on request to institutional researchers. Corresponding author: M Niaz Asadullah, Faculty of Economics and Administration, University of Malaya, Kuala Lumpur 50603, Malaysia. Email: m.niaz@um.edu.my.
} 


\section{Introduction}

Closing the male-female gap in secondary schooling is a key Sustainable Development Goals (SDGs) target. Limited numbers of schools for girls is one aspect of the problem. In many developing countries, governments are increasingly collaborating with non-state providers to expand educational opportunities to girls from marginalized communities. For instance, the madrasah education systems in Indonesia, Nigeria, and Bangladesh served as low-cost platforms to achieve universal education and the target of gender equity in schooling. This strategy has been supported by international development agencies (World Bank, 2011; ADB, 2014) and has led to "feminization" of madrasah enrolment in many countries (Hefner and Zaman, 2006; Asadullah and Chaudhury, 2009). In a similar vein, governments in many Muslim countries have collaborated with madrasah educated religious leaders such as Imams (i.e., Islamic preachers who lead prayers in the mosque) and maulvis to promote socially desirable reproductive behavior in rural areas (Roudi-Fahimi 2004). ${ }^{\mathrm{i}}$ Yet,the policy implications of partnership with faith schools and religious leaders for achieving gender equality have not been documented.

School education is expected to produce gender equitable outcomes. Greater educational provision can reduce violence within marriage (Mocan and Cannonier, 2012), increase participation in paid work (Mammen and Paxson 2000) and help break down restrictive social norms and gender perceptions such as entry of women into "male" occupations such as politics (Goetz, 2003). Female schooling is also widely believed to delay marriage and improve women's status within the household (Brown, 2012; Andalón, Williams, and Grossman, 2014) thereby creating a virtuous cycle between education and gender equality (Schuler 2007).

Nonetheless, evidence also suggests that secular schools paradoxically can reproduce exclusionary gender norms and prepare girls for traditional social roles (Jeffrey, Jeffery and Jeffery 2008; Murphy-Graham, 2009; Bartlett, 2007; DeJaeghere and Lee 2011; Chisamya, DeJaeghere, Kendall and Khan 2013; Fernandes 2014). This is partly because school textbooks around the developing world portray women in traditional occupational roles and encourage stereotypes regarding the division of labor within marriage (Blumberg, 2015). Equally, madrasah education is widely held to reinforce traditional values in girls in ways that may have substantial returns in the marriage market by helping them become a better wife (Raynor 2005; 2008). There is evidence to indicate significant conservatism amongst female madrasah graduates in relation to women's roles, supporting a traditional patriarchal social structure where boys are preferred and supported both for higher education and employment, while girls play a home-making role (Asadullah and Chaudhury, 2010). As lowcost schools such as madrasahs are increasingly relied upon to promote universal schooling, the full implications of their impact on values and attitudes need to be better understood.

In Bangladesh, there are important differences within the Islamic faith education sector that create variation in the degree to which Islamic schools are regulated. Madrasahs without state recognition are free to teach their own curricula that can vary according to their funding and support base. These madrasahs limit interactions between students and teachers of opposite sex and the curriculum may not explicitly acknowledge women's roles in politics and the economy. Also, a significant number of madrasah graduates take up jobs in mosques and madrasahs across the country and make up for the large community of Imams and Maulvis. Therefore, what happens inside madrasahs is important not just for the economy, but also in terms of, implications for the persistence of patriarchal norms and attitudes in the society. By 
contrast, the curricula of recognized madrasahs are reviewed by government authorities and mandated to include mathematics and science education as well as reproductive health education. Thus there exist three different school types with important differences in the material taught as well as in the values imparted. Schools may also vary in the quality of education imparted with unrecognized madrasahs having the most variability in funding level and quality. Yet, research documenting the link between education in unrecognized madrasahs and issues such as moral openness, pluralism, and gender equity is absent.

We, therefore, complement the current debate on school quality in Bangladesh and elsewhere by examining whether adolescents enrolled in religious schools display hostile attitudes towards working women, gender equity, and other socio-economic values. We do so using data from a recently conducted survey, "Quality of Secondary School Madrasas Education in Bangladesh" (QSSMEB), on secondary teachers and students in rural Bangladesh. As a byproduct, our study also makes a small contribution to the international literature on the role that education, religion, and institutions play in forming beliefs that people hold on social and political issues (Rahman, 2004; Gentzkow and Shapiro, 2004; Clingingsmith, Khwaja, and Kremer, 2009; Hajj and Ugo, 2009; Shafiq, 2010; Campante and Chor, 2012).

The paper unfolds as follows. Section 2 provides an overview of madrasahs in Bangladesh and additionally discusses the link between education and social attitudes. Section 3 discusses the data and empirical strategy and methodology. Results are presented in section 5 . Section 6 concludes.

\section{Study Background}

\subsection{Secondary Madrasah Education in Bangladesh}

The institutional reform of madrasahs in Bangladesh since the early 1980s provides a good context for examining whether pro-gender attitudes have changed. Apart from reasons related to economic efficiency, madrasah education has been controversial from a gender view-point given that historically madrasahs in South Asia have only educated boys. Therefore, recognized madrasahs (as well as non-religious schools) were given financial incentives to increase the share of female students. Following the introduction of various reform schemes in the 1980s and 1990s, Bangladesh saw the emergence of a large number of newly recognized madrasahs. Today a larger proportion of secondary madrasahs are recognized by the government, strictly follow state-approved text-books, and survive on state subsidy. Most importantly, including recognized madrasahs in secondary education reform programs led to a boom in female education and changed the sex composition of these schools (Asadullah and Chaudhury, 2009). ${ }^{\text {ii }}$ These madrasahs embraced female students and teachers and hadplayed an important role in closing gender gaps in secondary school enrolment, a key Millennium Development Goal (MDGs) target. Half of the students in recognized secondary madrasahs today are female and more than $80 \%$ of the schools are co-educational. On the other hand, unrecognized madrasahs continue to remain single-sex and largely cater to boys. In 1980, 1\% of madrasah teachers were female. Today, it stands at $6.9 \%$. Before the secondary school female scholarship scheme, only $4.9 \%$ of madrasah students were female. However, between 1990 and 2003, female enrolment increased by 39 percentage points so that $47 \%$ of the madrasah students today are girls (Asadullah and Chaudhury, 2009).

The above features of the Bangladeshi recognized secondary madrasah system confirms the role that recognized madrasahs have played in improving access to secondary education, 
particularly for girls. These recognized madrasahs have altered the age-old practice of educating predominantly male students and embracing girls. This scenario is in stark contrast with other countries with large Muslim populations in South Asia and elsewhere, where most religious seminaries are unrecognized, predominantly single-sex, and still untouched by any significant changes in curriculum (Ahmad, 2004). An unknown number of these unrecognized madrasahs also operate in Bangladesh but entirely as single-sex Islamic schools limiting the scope for cross-gender interactions. Male teachers and graduates of unrecognized madrasahs run mosques and issue religious rulings on the conduct of men and women in the social space and can have a large impact on gender norms in rural communities.

These two streams of madrasahs also differ significantly regarding curricula and pedagogical conduct because of how they are governed. The management of unrecognized madrasahs is fragmented - they belong to different regional non-state bodies instead of operating under a single regulatory authority (Asadullah and Chaudhury 2016; World Bank 2010). On the other hand, recognized madrasahs have to adhere to prescribed curricula and are fully regulated by a central government madrasah education board which is also responsible for conducting public examinations. While all recognized madrasah students are taught using a standardized curriculum, the share of non-religious subjects (e.g., maths and science) and the emphasis on foreign languages (e.g., Arabic and Urdu) in unrecognized madrasah curricula varies depending on the regional body they are governed by. The latter type of madrasahs also do not have a homogenous grade structure - how students are organized for teaching purposes in the classroom depends on the study subjects in the curricula and the textbooks used. Therefore, not only the number of years required to complete the final stage of the education (i.e., Dawrae Hadith) differ across these institutions, the number of actual grades can also vary significantly (Sattar 2004). In sum, the co-existence of state recognized and unrecognized madrasahs in Bangladesh presents a unique institutional setting in which the link between "conservative" gender attitudes and religious education can be formally examined.

\subsection{Schooling, Social Cohesion, and Gender Attitudes}

Improved educational access can lead to higher social trust, and employment for women, and greater support for gender equality in politics and work (e.g., Helliwell and Putnam, 2007; Campante and Chor 2012). However, the positive effect of education can vary depending on the type of schooling (Gentzkow and Shapiro, 2004). Differences in schooling experience (because of differences in school curricula) can promote different norms and expectations for males and females at an early age. This, in turn, is likely to influence gender preferences and attitudes and affect post-education choices relating to marriage and employment. Faith school attendance is commonly associated with favorable civic values, traditional values and other positive behavioral outcomes (Dee, 2005; Hofmann-Towfigh, 2007; Figlio and Ludwig, 2012). Madrasah attendance may have similar returns by transmitting values such as obedience, trust, selflessness, and submission (Lukens-Bull, 2001). At the same time, efforts to empower rural women by expanding post-primary education through madrasahs may involve potential trade-offs that arise in the form of reproduction of conservative gender norms and inadequate preparation for political leadership, higher education, and outside employment.

Women in many Muslim countries are under-represented in politics (Coffe and Dilli 2014) and the labor market and lack voice at home (Groh and Rothschild 2012). This pattern is likely to be reinforced by religious institutions like madrasahs which can undermine female 
agency in and outside family life. Poor parents may demand such education as long as it is valued by prospective grooms in the marriage market (Winkelman, 2005). In South Asian context, rural communities may value supply of pious and competent home-makers (Jeffery et al., 2004). Quran literacy is considered an important qualification for a good wife, someone trained in a non-questioning acceptance. Quran literacy could also be valuable traits for a village woman which enables her to appropriately socialise her children in rural communities (Rao and Hussain, 2011). To the extent these are the motivations for educating girls in madrasahs, the positive potential of female schooling in madrasahs may not increase women's voice and agency in the household and society. Instead educating girls in madrasahs, particularly those not recognized by the state, is likely to reproduce gender inequality across generations. We conjecture several specific channels through which there can be polarization of views across madrasahs and non-religious schools.

First, madrasahs may provide limited "secular" education which leaves their students particularly vulnerable to patriarchal narratives on gender roles and customs. Madrasah curricula may not acknowledge and address issues of gender inclusion and can alienate even girls within the co-educational classrooms. Women may be educated about family and the well-being of children as their primary obligations thereby reinforcing the role of women as "homemakers and mothers". The curricula may represent women in a discriminatory way and/or portray girls in a subservient role reinforcing traditional gender stereotypes and consequently may not disrupt these commonly held ideas about gendered roles ${ }^{\mathrm{iii}}$.

Second, madrasahs may differ significantly regarding gender norms and practices. Most coeducational recognized madrasahs implement an Islamic dress code in the absence of a government prescribed rule. Students of unrecognized madrasahs are segregated in single-sex institutions. Also, most madrasahs impose gender-specific restrictions on teaching and learning practices and on campus social interactions which may indirectly reinforce certain forms of gender inequality as socially acceptable ${ }^{\mathrm{iv}}$.

Third, teachers facilitate the formation of students' attitude through the social channel. Attitudes and influences of teachers perpetuate gender differences (Wiseman et al., 2009). To the extent teachers in non-religious and religious schools differ in attitudes, school-specific differences in student attitudes can prevail despite the use of a state-approved curriculum. Madrasah teachers are relatively untrained compared to non-madrasah schools and as such may lack adequate preparation to understand and address gendered dimensions of school and classroom interactions.

Fourth, traditional madrasahs educate students in a restricted environment with limited exposure to working women. The students, therefore, tend to grow up in a segmented society, live in closed communities and devote a significant amount of time to religious activities and studies. They lack exposure to the secular media (e.g., TV, satellite channels, the internet). ${ }^{\mathrm{v}}$ Thus, madrasah youths in rural communities are "socialized" to behave according to religious values by means of the education system.

The issue of attitudinal differences across Islamic and non-religious schools has been partially investigated for rural Bangladesh by Asadullah and Chaudhury (2010) who used data on a small sample of female graduates of recognized secondary schools and madrasahs. The authors examined data on teachers and female graduates to explore variation in attitudes across secondary schools and state recognized madrasahs towards working mothers, higher education for girls, and political regimes. They found that madrasah graduates were less in 
favour of higher education for girls and working mothers, consider housewives best for raising children, and indicate a preference for large families. However, they neither look at unrecognized madrasahs nor address the issue of the gender gap in attitudes. Therefore, we revisit the issue using a more comprehensive dataset that allows comparison of student attitudes by gender and school types and test some of the pathways underlying the madrasah effect on gender attitudes.

Lastly, in some instances, development partners and the government of Bangladesh have engaged with local level madrasah educated Islamic leaders to advocate behavioral and attitudinal change in socio-demographic outcomes in rural communities (USAID 2007). For instance, USAID introduced a program named the "Leaders of Influence", which trained more than 20,000 religious and other community leaders on national development goals and emphasized the importance of democratic governance, tolerance. vi This was seen as a potentially low-cost mechanism to reach out to the poor who are often difficult to reach by conventional public institutions. However, the exact impact of these initiatives on fertility and contraception choices is not known, particularly differentiating between Imams from the Aliyah and Qawmi traditions. Equally less known is the reproductive behavior and demographic structure of families of teachers from these two streams of madrasahs in Bangladesh. Available evidence indicates that madrasah graduates are more likely to believe that the optimal number of children is up to God (Asadullah and Chaudhury 2010). If teachers of Aliyah and Qawmi madrasahs differ regarding fertility preference that can indicate fundamental differences in the values and attitudes they hold. This would also have implications for gender attitudes among adolescents taught by them.

\section{Data source, sample description, and methodology}

Data used in this paper comes from the QSSMEB survey, which was purposefully designed and implemented by the authors in 2008 in rural Bangladesh with financial support from the World Bank. Appendix A (available in Supplementary Materials) provides further details on the survey design along with descriptive statistics. Our primary sample comprised of students aged between 14-17 years and enrolled in grade 8 (or equivalent) in sample schools. Summary statistics are presented in Appendix Table A1 (available in Supplementary Materials).

Table 1 summarizes student attitudinal responses to gender stereotype related questions; responses are on a five-point likert scale. Gender-based restrictions on dress code, social interactions and classroom organizations when combined with differences in teacher attitudes and curriculum can create gender divisions in attitudes. Therefore we expect gender attitudinal gaps across schools and recognized madrasahs to be smaller when compared to unrecognized madrasahs. Since we are primarily interested in the role of madrasah exclusively educating Muslim children, we present data separately for Hindu and Muslim children. Comparing rows 1 and 2 in Table 1, it is evident that Hindu children have an almost identical attitudinal profile when compared to their peers in non-religious schools. This implies that leaving Hindu children out of the sample does not significantly alter the mean attitude score of our sample non-religious schools. Looking at rows 2-4, however, an attitudinal gap is clear between schools and madrasahs. School students show less support for gender stereotypes compared to recognized madrasah students while traditional madrasah students demonstrate the least aversion to gender stereotypes. Since religious affiliation has 
no role in gender attitudes, this suggests that the observed gap between madrasahs and schools is not owing to the presence of non-Muslim faith students in the latter. For the same reason, our multivariate analysis of gender attitudes in section 4 is restricted to Muslim students only.

Additional patterns emerge when we repeat the descriptive analysis by gender. Non-madrasah school girls show very little support for gender stereotypes (the mean scores close to 3). ${ }^{\text {vi }}$ Support is significant among madrasah students where traditional madrasah girls systematically drive the result. Attitude scores for recognized madrasahs are slightly higher than that in non-madrasah school sample. However, irrespective of school or madrasah attended, boys systematically display greater support for gender stereotypes. Paradoxically this leads to a smaller gender gap in attitude in traditional madrasahs and a much larger one in non-madrasah schools.

\section{[Table 1 about here]}

Data presented in Table 1 shows a clear link between institutions, gender, and adolescent attitudes. Given the correlations between student attitudes and school types reported in this section, we are interested to find out the extent to which common socio-economic backgrounds explain the correlations and the underlying pathways. We do this using regression analysis in section four.

Regarding empirical strategy, we use responses to gender equality questions (all measured on a scale of 1-5) as dependent variables and estimate ordered probit regression models. Table 1 confirms identical gender attitudes across religious groups confirm that the observed effect of madrasah is not capturing in-group norms among Muslims that are anti-women. Therefore, regression analysis is restricted to children of Muslim faith only. Interpreting the link between Islamic school attendance and gender attitudes needs to account for the fact that students attending Islamic schools differ from non-religious schools along several dimensions, many of which are potentially correlated with their gender attitudes. Madrasahs serve as a cheaper alternative to non-religious schools and is relatively more attractive to children from poor families (Asadullah, Chakrabarti, and Chaudhury, 2015; Asadullah and Chaudhury 2016). The regression specification, therefore, controls for individual characteristics (i.e., age of the student), socio-economic backgrounds (education of mother and father, assets at home, media exposure) and type of school attended as well as host of teacher characteristics (at the school level). ${ }^{\text {viii }}$ Responses to subjective questions can be noisy in that they are influenced by mental conditions of the respondent. Therefore, our models include a proxy for mental state, namely "being upset on the day before the interview".

Our main variables of interest are coefficients on two dummy indicators capturing registered and traditional madrasah attendance. Given curriculum reform in recognized madrasahs, attitudinal gaps between students and madrasahs can be expected to be smaller when compared to unrecognized madrasahs. However, the observed effect of madrasah attendance could also reflect non-curriculum related factors. Curriculum aside, non-religious schools and madrasahs differ regarding physical inputs. On average, schools have better physical facilities, are better inspected by the government and have a larger proportion of trained teachers (Asadullah and Chaudhury, 2016; World Bank, 2010). Therefore, we sequentially add controls for teacher backgrounds to test whether madrasah specific attitudes reflect the influence of conservative teachers (proxied by their family size and own schooling in madrasahs), the lack of human capital (proxied by experience and formal training) and/or 
absence of role model effect (proxied by female teachers). Lastly, we re-estimate the models over sub-samples that vary in terms of distance to urban centres. Comparing student attitudes across madrasahs in isolated vis-à-vis more proximate or developed regions can serve as a rough robustness test of the observed correlation between madrasah attendance and pro-social

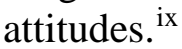

Lastly, madrasah enrolment is a choice made by one's parents and thus to some extent exogenous to the individual's attitude. Nonetheless, even in the absence of ability-based sorting, interpreting attitudinal gaps by school types is complicated by the fact children may acquire conservative gender attitudes from parents which are correlated with their school types. Alternatively, madrasahs may be catering to the preferences and promoting values that are culturally more appealing to parents in rural Bangladesh. ${ }^{x}$ For instance, madrasah educated children may be valued by parents for their religious orientation and filial piety as well as a source of old-age financial support (Asadullah, Chakrabarti, and Chaudhury, 2015). ${ }^{x i}$ Madrasahs could be catering to the preferences of some conservative rural households by imposing dress codes and gender-specific teaching and learning practices that are culturally more appealing to parents in rural Bangladesh. ${ }^{x i i}$ We do not have any credible solution to resolve the identification problem. It is hard to find variables in our data set that can simultaneously predict enrolment in two types of madrasahs without affecting trust attitudes. Our evidence is causal only to the extent controls for observed characteristics are reasonable proxies for unobserved correlates (e.g., parent's preferences) of student attitudes for household characteristics in terms of which students sort into madrasahs.

\section{Main results}

Table 2 presents the main regression results. Since our dependent variables are measured on a scale of 1-5, we use ordered probit regressions. Column (1) presents results from the regression analysis where student responses on three gender attitude measures are regressed on two madrasah dummies and the respondent's gender. In alternative regression specifications (the following two columns), we sequentially control for additional individual characteristics (i.e., age of the child), socio-economic background characteristics (education of mother and father, assets at home, media exposure) and teacher characteristics xiii . Responses to subjective questions can be noisy in that they are influenced by mental conditions of the respondent. Our models include a proxy for mental state, namely "being upset on the day of the interview".

\section{[Table 2 about here]}

We find strong evidence in support of the claim that student attitudes differ by school type (see model 1, table 2). Irrespective of types, madrasah students are less favorable to higher education for girls and female political leadership and consider boys to be more intelligent than girls. However, the coefficient on traditional madrasah dummy is much larger confirming that students tolerate gender stereotypes more when compared to their peers in recognized madrasahs and schools. The observed effect of madrasah attendance may still reflect the influence of socio-economic differences among students ${ }^{\text {xiv }}$. However, the results prevail even after controlling for common family backgrounds (see model 2, table 2).

In order to test what drives the madrasah effect, specification 3 adds several controls for teacher characteristics. These additional controls appear to explain the difference in attitudes associated with being enrolled in recognizedand unrecognized madrasahs relative to the 
reference group in all regressions ${ }^{\mathrm{xv}}$. These suggest a causal explanation lies in school and teacher characteristics - relative to non-faith based schools, madrasahs employ poorly trained, less experienced and socially conservative teachers who have large families (See appendix Table 2). They are also more likely to employ teachers who have only religious education. In models that allow for variation in these characteristics, it is seen that gender attitudes are significantly associated with teacher training and teacher family size. Controlling for these characteristics of schools and their teachers are sufficient to explain away the difference in student attitudes across school types that are observed in statistical models that do not account for these differences. ${ }^{\text {xvi }}$

Among other results, girls show significantly less support for gender stereotypes compared to boys. Children of fathers with post-secondary education also show significant aversion to gender stereotypes. In order to test the extent to which the observed madrasah effect is characterized by a gender-differentiated pattern, we look at the determinants of attitudes separately for boys and girls (see Table 3). Three findings are noteworthy. First, the stereotypical gender attitudes prevails both among boys and girls of recognized madrasahs. This is true even when we account for family background differences (see models 1 vs. 2). With control for teacher characteristics, however, the effect weakens and in most cases becomes insignificant (see model 3). Second, unrecognized madrasah attendance exerts a larger influence on female students ${ }^{\text {xvii }}$. However, the effect is very strong and significant for male sample for all three outcomes. The coefficient on the unrecognized madrasah dummy is negative and significant even after controlling for teacher backgrounds (specification 3). Third, the correlation between teacher fertility and student attitude is significant and positive only in the case of female students. Teachers of unrecognized madrasahs have larger families and have 2.5 children on average (Appendix Table 1). Average family size is about 0.5 children greater for this group than for teachers as a whole. While these are not large differences, it does suggest that unregistered madrasah teachers are more pro-natalist in nature and may impart values of a past era when higher fertility was the norm and women's roles were restricted. Their higher family size also indicates that they have been slow to respond to the nationwide changes in reproductive norms. ${ }^{\text {xiii }}$

\section{[Table 3 about here]}

On the basis of cross-section data, it is difficult to be conclusive about the causal evidence on the impact of madrasahs. Madrasah effect may mirror excessive gender discrimination and violence that children experience in their homes and communities (Chisamya, DeJaeghere, Kendall and Khan 2013). Controls for family factors in our model are incomplete and therefore the possibility that the positive, partial correlations between madrasah schooling and student attitudes reflect selection biases cannot be dismissed. Parents choosing a given school type may have unobserved characteristics that also shape student attitudes. In other words, adolescents may acquire conservative preferences from parents which are correlated with their school types.

\section{[Table 4 about here]}

To partially address omitted variable and reverse causality related concerns, we re-estimate the multivariate model of student attitude with control for school fixed effects in an ordinary linear regression (OLS) framework. ${ }^{\text {ix }}$ This exploits the fact that a significant proportion of children in rural Bangladesh experience a change in school type as they transit from primary 
(grades 1-5) to secondary (grades 6-10) schools. Regression estimates are based on linear probability models (see Table 4). Therefore, the result is specific to a small sub-population for whom school switching has occurred between types (i.e., madrasah and school or recognized and traditional madrasah). We find that among adolescents attending the same secondary school, exposure to traditional madrasah education at primary level also has an independent and sizeable effect on gender attitudes. However, the effect size is small, and the results are marginally significant. But the fixed effects analysis once again confirms that gender gap in attitude is a within (instead of between) school phenomenon, and it is entirely driven by the fact that boys systematically show greater support for stereotypical views. The female dummy is consistently negative and significant.

\section{Conclusion}

Women in developing countries face multiple constraints so that relaxing just one may not improve gender outcomes (Duflo, 2012). In the presence of social stereotypes among men against women's ability, improved economic opportunity per se is insufficient to ensure progress in female empowerment and participation in politics and higher education. In this context, increasing girls' school participation can help close gender gap in the society since schooling promotes inclusive and pro-social attitudes. However recent research warns about the limitations of fostering gender equity through school-based initiatives (e.g., Jeffrey and Basu 1996; Jeffery and Jeffery 1998). Evidence in support of the positive influence of female schooling on women's rights, gender roles, and political participation is also mixed (Friedman, Kremer, Miguel, and Thornton 2016). We add to this literature by studying the impact of a particular schooling experience, education in traditional madrasahs, vis-à-vis state recognized madrasahs and non-religious schools in rural Bangladesh.

Using data from a purposefully designed survey that over samples faith-based schools and allows us to explore school characteristics, we find that madrasah students in general and unrecognized madrasah students, in particular,, have unfavorable attitudes about women and their abilities compared to their peers non-religious schools. The effect is present even among female students irrespective of the type of madrasah attended while for male students it is more pronounced in case of unrecognized madrasahs. To the extent some of the differences in adolescent characteristics remain unobserved, the evidence presented in this study should be treated as suggestive. However, if causal, governments working to empower rural women by expanding post-primary education face numerous challenges related to these findings. Greater provision of educational services through faith based organizations can help achieve certain SDGs targets such as gender equality in access to schooling. But such partnership may limit the ability of developing countries to shift attitudes and norms among women and men about women's role in the society. Our research highlights the limited transformational capacity of schooling when girls are educated in madrasahs. The evidence presented suggests that madrasah schools may be imposing their own conservative social norms on students. They may be catering to the preferences of some conservative households and promoting values that are culturally more appealing to parents in rural Bangladesh. ${ }^{\mathrm{xx}}$ Therefore, future analysis of long-term pay-offs from the gains in educational access via madrasahs should take into account potential trade-offs that may arise in the form of conservative gender norms and attitudes.

In this connection, two areas deserve attention. In low-literacy rural environments, teachers are an important conduit for transmission of progressive views and social attitudes. We are 
able to show that attitudinal differences among students are explained by teacher characteristics that differ considerably across school type. The finding that higher proportions of female and trained teachers reduce support for traditional attitudes among girls highlights the importance of hiring more female teachers and improving provisions for teacher training. The significance of teacher/school characteristics highlights the importance of school quality measures in explaining the role of schools influencing gender normative outcomes. Since madrasahs (particularly unrecognized) lack both, trained teachers and female teachers, compared to schools, improvements in these aspects can help close the school-madrasah gap in terms of quality. In the past, reform initiatives have been limited to state recognized Islamic schools only. However, the Government of Bangladesh in April 2017 declared recognition of certificates of Dawrae Hadith under Qawmi Madrasah Education Boards as equivalent to Masters Degree in Islamic Studies and Arabic (The Daily Star, 2017) while simultaneously announcing a plan to launch a new stream of government madrasahs specializing in Arabic and Urdu languages (Dhaka Tribune, 2017). These developments can serve as critical junctures for institutional development of the madrasah sector in terms of pushing for reforms focused on learning quality and teacher capacity. The other issue of policy relevance is the growing concern over gender stereotypes in textbook contents. The persistence of traditional gender stereotypes among school-going children in our study can partly arise because textbooks disseminate gender bias through stereotypical depictions of men and women within the school curriculum. This in turn reinforces traditional gender stereotypes among students. Indeed earlier in 2017, the government of Bangladesh revised the curricula and introducing new textbooks that portrayed girls in a more subservient and conservative roles. ${ }^{\mathrm{xxi}}$ Therefore, critical reflection is required on gender contents of teaching and learning materials used in schools as well as madrasahs. Greater presence of female teachers, better teacher training and introduction of gender balanced teaching and learning materials and textbooks can help close gender and school-madrasah gaps in student attitudes in Bangladesh. 


\section{Reference}

Abid, N., Islam, O., Bosan A, et al. (2010). Pakistan's fight against poliomyelitis: introducing innovative strategies to address challenges and attain the goal of eradication, Eastern Mediterranean Health Journal, 16, S5-14.

ADB (2014) Indonesia: Madrasah Education Development Project, completion report. Asian Development Bank http://www.adb.org/sites/default/files/projdocs/2014/37475-013-pcr.pdf

(ADB)

Ahmad, M. (2004). Madrasah Education in Pakistan and Bangladesh. In SatuLimaye, Robert Wirsing and Mohan Malik (eds.) Religious Radicalism and Security in South Asia. Asia-Pacific Center for Security Studies: Honolulu.Ahmed,

Anis, Kazi (2017). Bangladesh’s Creeping Islamism, The New York Times. 03 February 2017.

Andalón, M., Williams, J. and Grossman, M. (2014). Empowering Women: The Effect of Schooling on Young Women's Knowledge and Use of Contraception. IZA Discussion Paper No. 7900.

Asadullah, M. N. and Chaudhury, N. (2009). Holy alliances: public subsidies, Islamic high schools, and female schooling in Bangladesh, Education Economics, 17(3), 377-394.

Asadullah, M N. and Chaudhury, N. (2010). Religious Schools, Social Values, and Economic Attitudes: Evidence from Bangladesh, World Development, 38(2), 205-217.

Asadullah, M. N., Chakrabarti, R. \& Chaudhury, N. (2015). What Determines Religious School Choice? Theory and Evidence from Rural Bangladesh, Bulletin of Economic Research, 67(2), 186-207.

Asadullah, M N. and Chaudhury, N. (2016). To Madrasahs or Not to Madrasahs: The Question and Correlates of Enrolment in Islamic Schools in Bangladesh, International Journal of Educational Development, 49, 55-69.

Blumberg, R. L. (2015) "Eliminating gender bias in textbooks: Pushing for policy reforms that promote gender equity in education" Background paper prepared for the Education for all global monitoring report 2015, Education for All 2000-2015: achievements and challenges.

Berman, Eli (2000). Sect, Subsidy, and Sacrifice: An Economist's View of Ultra-Orthodox Jews, Quarterly Journal of Economics, 115(3), 905-953.

Bisin, A. and Verdier, T. (2001). The Economics of Cultural Transmission and the Dynamics of Preferences, Journal of Economic Theory, 97(2), 298-319.

Brown, G. (2012) Out of Wedlock, Into School: Combating Child Marriage through Education, London: The Office of Gordon and Sarah Brown.

Campante, F. R. and Chor, D. (2012). Why was the Arab World Poised for Revolution? Schooling, Economic Opportunities, and the Arab Spring, Journal of Economic Perspectives, 26(2), 167-188.

Clingingsmith, D., Khwaja, A., and Kremer, M. (2009). Estimating the Impact of the Hajj: Religion and Tolerance in Islam's Global Gathering, Quarterly Journal of Economics, 124(3), 1133-1170.

Chisamya, G., DeJaeghere, J., Kendall, N., Khan, M.A. (2013) Gender and education for all: Progress and problems in achieving gender equity, International Journal of Educational Development, 32(6), 743-755.

Coffe, H. and Dilli, S. (2014) "The gender gap in political participation in Muslim-majority countries,” International Political Science Review, 36(5), 526-544.

Dee, Thomas (2005) “The Effects of Catholic Schooling on Civic Participation", International Tax and Public Finance, 12(5), 605-625. 
DeJaeghere, J. and Lee, S.K. (2011). What matters for marginalized girls and boys: a capabilities approach to exploring marginalization and empowerment in Bangladesh, Research in Comparative and International Education, 6(1), 27-42.

Duflo, Esther (2012) Women Empowerment and Economic Development. Journal of Economic Literature, 50(4), 1051-79.

Fernandes, Leela (2014) Routledge Handbook of Gender in South Asia. Routledge.

Figlio, David and Jens Ludwig (2012) Sex, Drugs, and Catholic Schools: Private Schooling and Non-Market Adolescent Behaviors, German Economic Review, 13(4), 385-415.

Friedman, Willa, Kremer, M., E. Miguel, and R. Thornton (2016) "Education as Liberation". Economica, 83(329), 1-30, 01.

Gentzkow, M. and Shapiro, J., M. (2004) Media, Education and Anti-Americanism in the Muslim World, Journal of Economic Perspectives, 18(3), 117-133.

Griswood, Eliza (2005). The Next Islamist Revolution?, January 23, New York Times; Magazine Desk.

Guiso, L., Sapienza, P. and Zingales, Luigi (2003) People's Opium? Religion and Economic Attitudes, Journal of Monetary Economics, 50(2), 225-282.

Goetz, Anne Marie (2003) “Women's education and political participation”. Background paper prepared for the Education for All Global Monitoring Report 2003/4, Gender and Education for All: The Leap to Equality.

Hefner, Robert W. and Zaman, Muhammad Qasim (2006) Schooling Islam: Modern Muslim Education. Princeton University Press.

Helliwell, J., and R. Putnam (2007). Education and Social Capital, Eastern Economics Journal, 33(1), 1-19.

Hajj, Mandana and Panizza, Ugo (2009) "Religion and education gender gap: Are Muslims different?”, Economics of Education Review, 28(3), 337-344.

Hofmann-Towfigh, Nadi (2007). Do students' values change in different types of schools? Journal of Moral Education, 36(4), 453-473.

Huber D, Saeedi N, Samadi AK. (2010). Achieving success with family planning in rural Afghanistan. Bulletin of World Health Organization, 88(3), 227-31.

Groh, M. and Rothschild, C. (2012). "Oil, Islam, Women, and Geography: A Comment on Ross (2008)", Quarterly Journal of Political Science, 7(1), 69-87.

Jeffrey, R. and Basu, A. M. (1996). Girls' Schooling, Women's Autonomy and Fertility Change in South Asia. New Delhi: Sage Publications.

Jeffery, Patricia and Jeffery, Roger (1998). Silver Bullet or Passing Fancy? Girls' education and population policy. In Cecile Jackson and Ruth Pearson (eds): Feminist Visions of Development: Gender Analysis and Policy.R outledge, London. pp. 235-254

Jeffery, P., Jeffery, R., et al. (2004). Islamization, gentrification and domestication: a girls' Islamic course and rural Muslims in western Uttar Pradesh, Modern Asian Studies 38(1), 1-53.

Jeffrey, Craig, Jeffery, Patricia and Jeffery, Roger (2008) Degrees without freedom? Education, Masculinities, and Unemployment in North India. Stanford, CA. Stanford University Press.

Jeffery, Patricia Roger Jeffery and Craig Jeffrey (2012). Leading by Example? Women madrasah teachers in rural north India, In Masooda Bano and Hilary Kalmbach (eds): Women, Leadership and Mosques: Changes in Contemporary Islamic Authority. Leiden/Boston: Brill.

Lehrer, E. L. (2009). "Religion, Human Capital Investments and the Family in the United States,” Institute for the Study of Labor (IZA) Discussion Papers 4279.

Lenski, G. (1963). The religious factor. New York: Anchor Books. 
Lloyd, C. B. (2013). Education for Girls: Alternative Pathways to Girls' Empowerment. London, Girl Hub, Nike Foundation/UK Department for International Development.

Loehlin, J.C. (2005). Resemblance in Personality and Attitudes Between Parents and Their Children: Genetic and Environmental Contributions in: S. Bowles, et al Princeton University Press.

Lintner, Bertil (2003). Religious Extremism and Nationalism in Bangladesh, Faultlines, 14 (The Institute of Conflict Management, New Delhi).

Lukens-Bull, R.A. (2001). Two sides of the same coin: modernity and tradition in Islamic education in Indonesia, Anthropology and Education Quarterly 32(3), 350-372.

Mammen, K., and C. Paxson (2000). Women's work and economic development, The Journal of Economic Perspectives 14(4), 141-164.

Munshi, K. and Myaux, J. (2006) Social norms and the fertility transition, Journal of Development Economics, 80(1), 1-38.

Mocan, N. H. and Cannonier, C. (2012). Empowering Women Through Education: evidence from Sierra Leone. NBER Working Paper No. 18016.

Murphy-Graham, E. (2008). Opening the black box: women's empowerment and innovative secondary education in Honduras, Gender and Education, 20(1), 31-50.

Obermeyer CM. (1994). Reproductive choice in Islam: gender and state in Iran and Tunisia. Studies in Family Planning, 25(1), 41-51.

Orubuloye, I.O., Caldwell, J.C., Caldwell, P. (1993) The role of religious leaders in changing sexual behaviour in Southwest Nigeria in an era of AIDS. Health Transition Review. 3, 93-104 (Suppl.).

Rahman, T. (2004). Denizens of alien worlds: a survey of students and teachers at Pakistan's Urdu and English language-medium schools, and madrasahs, Contemporary South Asia, 13(3), 307-326.

Rao, N. and Hossain, M. I. (2011). Confronting poverty and educational inequalities: Madrasas as a strategy for contesting dominant literacy in rural Bangladesh, International Journal of Educational Development, 31(6), 623-633.

Rao, A., Kelleher, D. (2005). Is there life after gender mainstreaming? Gender and Development, 13(2), 57-69.

Raynor, J. (2005). Educating girls in Bangladesh: Watering a neighbour's tree? In: Aikman, S., Unterhalter, E., eds. Beyond Access: Transforming Policy and Practice for Gender Equality in Education. Oxfam Publications, London.

Raynor, J. (2008). Schooling girls: an intergenerational study of women's burdens in rural Bangladesh, In: Gender Education and Equality in a Global Context: Conceptual Frameworks and Policy Perspectives, Routledge, London.

Roudi-Fahimi F. (2004). Islam and Family Planning. Washington, DC: Population Reference Bureau.

Sattar, Abdus Sattar (2004). Madrassa Education in Bangladesh and Its Impact on Social Life (in Bengali). Islamic Foundation, Dhaka.

Schuler, S. (2007). Rural Bangladesh: sound policies, evolving gender norms, and family strategies, In Maureen Lewis and Marlaine Lockheed (eds.): Exclusion Gender and Education: Case Studies from the Developing World, Center for Global Development, Washington, DC.

Shafiq, M. Najeeb (2010). Do education and income affect support for democracy in Muslim countries? Evidence from the Pew Global Attitudes Project, Economics of Education Review, 29(3), 461-469.

Shah, S. F. (2012). Gender inclusion: a neglected aspect of the English textbooks in Pakistan, International Journal of Social Science and Education, 3(1), 118-27. 
Simmons R, Baqee L, Koenig MA, et al. (1988). Beyond supply: the importance of female family planning workers in rural Bangladesh. Studies in Family Planning, 19, 29-38.

The Daily Star (2017). Qawmi Madrasa Dawrae Hadith gets recognition The Daily Star, April 11, 2017. ((accessed on 5 May 2017: http://www.thedailystar.net/country/qawmi-madrasa-dawrae-hadith-gets-recognition1389823)

The Dhaka Tribune (2017). Islamic Foundation plans new stream of madrasas with focus on Arabic, Urdu, July 28. (accessed on 2 August 2017: http://www.dhakatribune.com/bangladesh/education/2017/07/28/islamic-foundationplans-new-stream-madrasas-focus-arabic-urdu/)

Underwood, C. R., and Kamhawi, S. S. (2014). Friday sermons, family planning and gender equity attitudes and actions: evidence from Jordan, Journal of Public Health, 37(4), 641-8.

UNESO (2016) Gender Review: Creating Sustainable Futures for All. Global Education Monitoring Report series, UNESCO.

USAID (2007) Long-term and permanent methods of family planning in Bangladesh.

Warwick, D.P. (1986). The Indonesian family planning program: Government influence and client choice, Population Development Review, 12, 453-90.

Weber, M. (1930). The protestant ethnic and the spirit of capitalism. London: Unwin Hyman.

World Bank (2010) Secondary School Madrasahs in Bangladesh: Incidence, Quality and Implications for Reform, Bangladesh Development Series Paper No. 27.

World Bank (2011) Learning for All - World Bank Group Education Strategy 2020. World Bank: Washington DC.

World Bank (2012) World Development Report: Gender Equality and Development. World Bank: Washington DC.

Wiseman, A., Baker, D., Riegle-Crumb, C., Ramirez, F., (2009). Shifting gender effects: opportunity structures, institutionalized mass schooling, and cross-national achievement in mathematics. In David P. Baker and Alexander W. Wiseman (eds.): Gender, Equality and Education from International and Comparative Perspectives (International Perspectives on Education and Society, Volume 10), Emerald Group Publishing Limited, Bingley.

Winkelman, M. (2005) "Everyday Life in a Girls' Madrasah in Delhi,” in Radhika, Ch., Jeffery, P. eds. Educational Regimes in Contemporary India (New Delhi: Sage Publications). 
Table 1: Gender attitudes of students (grade 8) by school type and gender

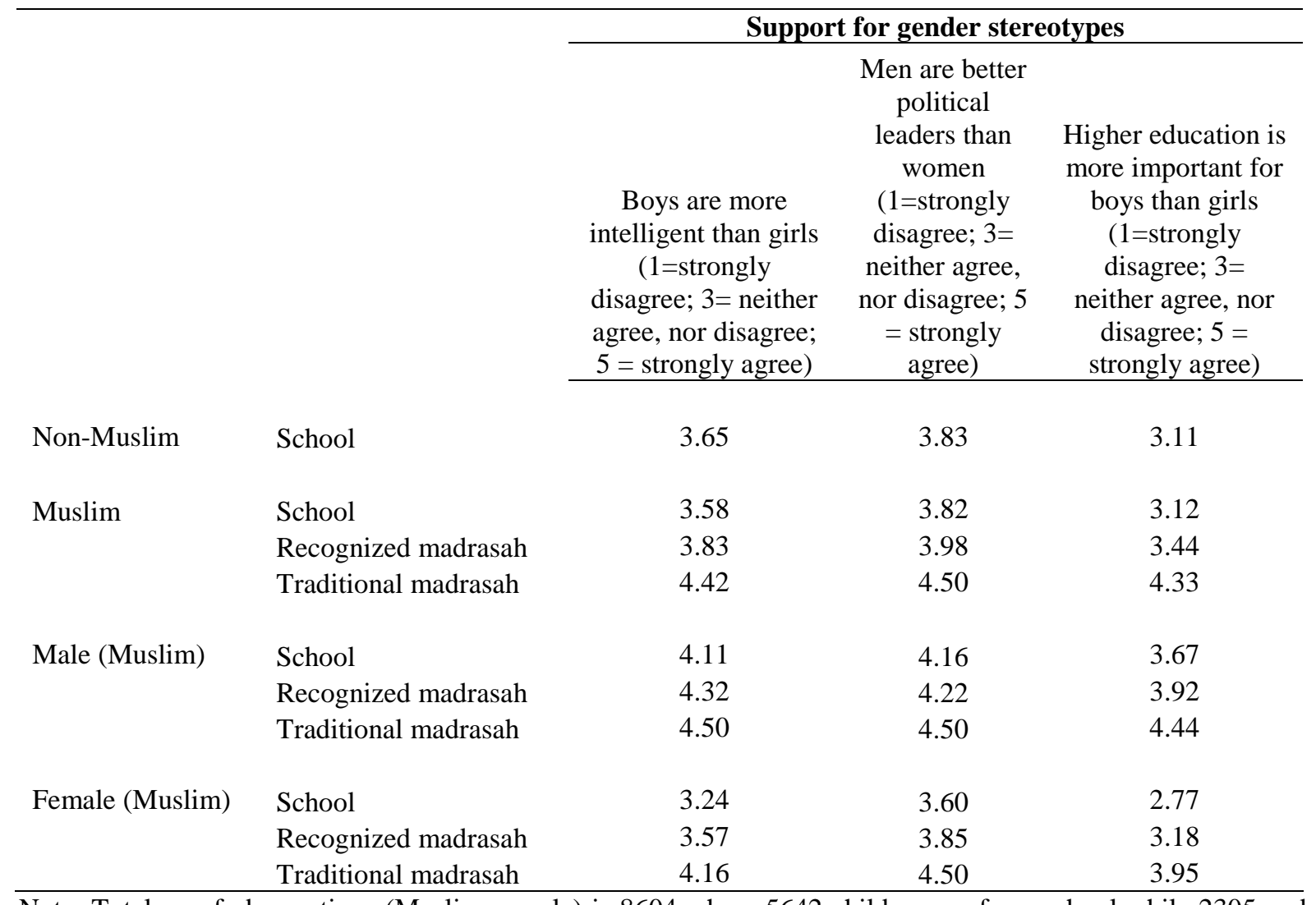

Note: Total no of observations (Muslim sample) is 8604 where 5642 children are from school while 2305 and 657 are from recognized and traditional madrasahs. Non-Muslim children ( $\mathrm{N}=593)$ are exclusively in school. 
Table 2: Ordered Probit estimates of determinants of gender attitudes

\begin{tabular}{|c|c|c|c|c|c|c|c|c|c|}
\hline & \multicolumn{3}{|c|}{$\begin{array}{l}\text { Boys are more intelligent } \\
\text { than girls }\end{array}$} & \multicolumn{3}{|c|}{$\begin{array}{l}\text { Men are better political leaders } \\
\text { than women }\end{array}$} & \multicolumn{3}{|c|}{$\begin{array}{c}\text { Higher education is more important for boys than } \\
\text { girls }\end{array}$} \\
\hline & (1) & (2) & (3) & (1) & (2) & (3) & (1) & (2) & (3) \\
\hline \multicolumn{10}{|l|}{ Secondary School type attended } \\
\hline Recognized madrasah & $\begin{array}{c}0.238 \\
(8.74)^{* *}\end{array}$ & $\begin{array}{c}0.238 \\
(8.51)^{* *}\end{array}$ & $\begin{array}{l}-0.008 \\
(0.11)\end{array}$ & $\begin{array}{c}0.146 \\
(5.38)^{* *}\end{array}$ & $\begin{array}{l}0.123 \\
(4.41)^{* *}\end{array}$ & $\begin{array}{c}-0.125 \\
(1.76)+\end{array}$ & $\begin{array}{c}0.263 \\
(9.90)^{* *}\end{array}$ & $\begin{array}{c}0.235 \\
(8.57)^{* *}\end{array}$ & $\begin{array}{l}0.028 \\
(0.41)\end{array}$ \\
\hline Unrecognized madrasah & $\begin{array}{c}0.585 \\
(11.36)^{* *}\end{array}$ & $\begin{array}{c}0.499 \\
(7.95)^{* *}\end{array}$ & $\begin{array}{c}0.14 \\
(1.28)\end{array}$ & $\begin{array}{c}0.589 \\
(11.54)^{* *}\end{array}$ & $\begin{array}{c}0.517 \\
(8.25)^{* *}\end{array}$ & $\begin{array}{l}0.122 \\
-1.12\end{array}$ & $\begin{array}{c}0.858 \\
(17.05)^{* *}\end{array}$ & $\begin{array}{c}0.658 \\
(10.77)^{* *}\end{array}$ & $\begin{array}{c}0.4 \\
(3.77)^{* *}\end{array}$ \\
\hline \multicolumn{10}{|l|}{ Child characteristics } \\
\hline Female & $\begin{array}{c}-0.698 \\
(27.52)^{* *}\end{array}$ & $\begin{array}{l}-0.677 \\
(26.17)^{* *}\end{array}$ & $\begin{array}{c}-0.68 \\
(25.78)^{* *}\end{array}$ & $\begin{array}{c}-0.436 \\
(17.44)^{* *}\end{array}$ & $\begin{array}{c}-0.412 \\
(16.10)^{* *}\end{array}$ & $\begin{array}{c}-0.421 \\
(16.13)^{* *}\end{array}$ & $\begin{array}{c}-0.662 \\
(26.92)^{* *}\end{array}$ & $\begin{array}{c}-0.657 \\
(26.11)^{* *}\end{array}$ & $\begin{array}{c}-0.652 \\
(25.41)^{* *}\end{array}$ \\
\hline Child age & & $\begin{array}{l}-0.127 \\
(1.36)\end{array}$ & $\begin{array}{c}-0.11 \\
(1.17)\end{array}$ & & $\begin{array}{c}0.267 \\
(3.00)^{* *}\end{array}$ & $\begin{array}{c}0.277 \\
(3.08)^{* *}\end{array}$ & & $\begin{array}{l}-0.005 \\
(0.05)\end{array}$ & $\begin{array}{l}0.014 \\
(0.15)\end{array}$ \\
\hline Child age, squared & & $\begin{array}{l}0.005 \\
(1.42)\end{array}$ & $\begin{array}{l}0.004 \\
(1.21)\end{array}$ & & $\begin{array}{l}-0.009 \\
(2.79)^{* *}\end{array}$ & $\begin{array}{c}-0.009 \\
(2.86)^{* *}\end{array}$ & & $\begin{array}{l}0.001 \\
(0.38)\end{array}$ & $\begin{array}{c}0 \\
(0.13)\end{array}$ \\
\hline Student upset & & $\begin{array}{l}0.036 \\
(1.28)\end{array}$ & $\begin{array}{c}0.044 \\
(1.56)\end{array}$ & & $\begin{array}{c}0.008 \\
(0.27)\end{array}$ & $\begin{array}{l}0.013 \\
(0.46)\end{array}$ & & $\begin{array}{c}0.086 \\
(3.08)^{* *}\end{array}$ & $\begin{array}{c}0.09 \\
(3.24)^{* *}\end{array}$ \\
\hline \multicolumn{10}{|l|}{ Family background } \\
\hline Mother's edu: grade 5 completed & & -0.044 & -0.047 & & $\begin{array}{l}-0.019 \\
(0.56)\end{array}$ & $\begin{array}{r}-0.025 \\
(0.74)\end{array}$ & & $\begin{array}{r}-0.064 \\
(189)+\end{array}$ & -0.063 \\
\hline Mother's edu: grades 6-9 completed & & $\begin{array}{l}-0.049 \\
(1.34)\end{array}$ & $\begin{array}{l}-0.055 \\
(1.51)\end{array}$ & & $\begin{array}{l}0.026 \\
(0.71)\end{array}$ & $\begin{array}{l}0.024 \\
(0.64)\end{array}$ & & $\begin{array}{c}-0.133 \\
(3.72)^{* *}\end{array}$ & $\begin{array}{c}-0.138 \\
(3.85)^{* *}\end{array}$ \\
\hline Mother's edu: grades 10 completed & & $\begin{array}{l}0.002 \\
(0.06)\end{array}$ & $\begin{array}{l}0.001 \\
(0.03)\end{array}$ & & $\begin{array}{l}0.031 \\
(0.74)\end{array}$ & $\begin{array}{l}0.033 \\
(0.78)\end{array}$ & & $\begin{array}{l}-0.052 \\
(1.25)\end{array}$ & $\begin{array}{l}-0.058 \\
(1.4)\end{array}$ \\
\hline Mother's edu: grade $10+$ completed & & $\begin{array}{l}-0.064 \\
(1.15)\end{array}$ & $\begin{array}{l}-0.064 \\
(1.15)\end{array}$ & & $\begin{array}{c}0.097 \\
(1.72)^{+}\end{array}$ & $\begin{array}{l}0.092 \\
(1.63)\end{array}$ & & $\begin{array}{l}-0.005 \\
(0.08)\end{array}$ & $\begin{array}{l}-0.012 \\
(0.21)\end{array}$ \\
\hline Father's edu: grade 5 completed & & $\begin{array}{l}-0.029 \\
(0.71)\end{array}$ & $\begin{array}{r}-0.035 \\
(0.85)\end{array}$ & & $\begin{array}{l}0.001 \\
(0.03)\end{array}$ & $\begin{array}{l}-0.003 \\
(0.08)\end{array}$ & & $\begin{array}{l}-0.059 \\
(1.47)\end{array}$ & $\begin{array}{l}-0.064 \\
(1.58)\end{array}$ \\
\hline Father's edu: grades 6-9 completed & & $\begin{array}{l}-0.046 \\
(1.28)\end{array}$ & $\begin{array}{l}-0.052 \\
(1.44)\end{array}$ & & $\begin{array}{l}-0.023 \\
(0.64)\end{array}$ & $\begin{array}{c}-0.029 \\
(0.8)\end{array}$ & & $\begin{array}{l}-0.049 \\
(1.38)\end{array}$ & $\begin{array}{l}-0.053 \\
(1.49)\end{array}$ \\
\hline Father's edu: grades 10 completed & & $\begin{array}{l}-0.04 \\
(1.04)\end{array}$ & $\begin{array}{r}-0.039 \\
(1.03)\end{array}$ & & $\begin{array}{r}-0.028 \\
(0.72)\end{array}$ & $\begin{array}{r}-0.022 \\
(0.58)\end{array}$ & & $\begin{array}{l}0.003 \\
(0.08)\end{array}$ & $\begin{array}{l}0.003 \\
(0.08)\end{array}$ \\
\hline Father's edu: grade $10+$ completed & & $\begin{array}{c}-0.147 \\
(3.73)^{* *}\end{array}$ & $\begin{array}{c}-0.143 \\
(3.64)^{* *}\end{array}$ & & $\begin{array}{c}-0.136 \\
(3.47)^{* *}\end{array}$ & $\begin{array}{c}-0.137 \\
(3.50)^{* *}\end{array}$ & & $\begin{array}{c}-0.158 \\
(4.09)^{* *}\end{array}$ & $\begin{array}{c}-0.155 \\
(4.00)^{* *}\end{array}$ \\
\hline Newspaper-magazine at home & & 0.051 & 0.049 & & -0.071 & -0.071 & & 0.044 & 0.042 \\
\hline Asset index & & $\begin{array}{l}-0.005 \\
(0.42)\end{array}$ & $\begin{array}{l}-0.002 \\
(0.17)\end{array}$ & & $\begin{array}{c}0.01 \\
(0.79)\end{array}$ & $\begin{array}{l}0.012 \\
(0.91)\end{array}$ & & $\begin{array}{l}-0.032 \\
(2.49)^{*}\end{array}$ & $\begin{array}{l}-0.031 \\
(2.40)^{*}\end{array}$ \\
\hline Teacher characteristics & & & & & & & & & \\
\hline Proportion of female teachers & & & $\begin{array}{l}0.043 \\
(0.42)\end{array}$ & & & $\begin{array}{c}0.262 \\
(2.53)^{*}\end{array}$ & & & $\begin{array}{l}-0.036 \\
(0.37)\end{array}$ \\
\hline Mean teacher experience & & & $\begin{array}{l}-0.006 \\
(2.17)^{*}\end{array}$ & & & $\begin{array}{l}-0.001 \\
(0.45)\end{array}$ & & & $\begin{array}{l}0.001 \\
(0.35)\end{array}$ \\
\hline Proportion of trained teachers & & & $\begin{array}{l}-0.061 \\
(1.13)\end{array}$ & & & $\begin{array}{l}0.043 \\
(0.81)\end{array}$ & & & $\begin{array}{c}-0.185 \\
(3.52)^{* *}\end{array}$ \\
\hline Proportion of teachers with religious & & & 0.494 & & & 0.747 & & & 0.28 \\
\hline
\end{tabular}


education only?

Proportion of non-Muslim teachers

Mean family size of teachers

$\mathrm{N}$

Pseudo R

Note: (a) All regressions control for district dummies, student's age and house

in parenthesis

\begin{tabular}{|c|c|c|c|c|c|c|c|c|}
\hline & & $\begin{array}{c}(3.54)^{* *} \\
0.097 \\
(0.94) \\
0.034 \\
(4.24)^{* *}\end{array}$ & & & $\begin{array}{c}(5.34)^{* *} \\
0.303 \\
(2.92)^{* *} \\
0.001 \\
(0.11)\end{array}$ & & & $\begin{array}{c}(2.07) * \\
0.013 \\
(0.13) \\
0.018 \\
(2.24)^{*}\end{array}$ \\
\hline 8451 & 8451 & 8451 & 8585 & 8434 & 8434 & 8408 & 8408 & 8408 \\
\hline 0.04 & 0.05 & 0.05 & 0.02 & 0.04 & 0.04 & 0.05 & 0.06 & 0.06 \\
\hline
\end{tabular}

(b) Standard errors are corrected for clustering effect at school level. (c) t-statistics 
Table 3: Ordered probit estimates of determinants of gender attitudes by sex

\begin{tabular}{|c|c|c|c|c|c|c|c|c|c|}
\hline \multirow[b]{3}{*}{ MALE } & \multirow[b]{3}{*}{ (1) } & \multirow{2}{*}{\multicolumn{2}{|c|}{ oys more intelligent than girls }} & \multirow{2}{*}{\multicolumn{3}{|c|}{ Men better political leaders than women }} & \multicolumn{3}{|c|}{ Higher education more important for boys than } \\
\hline & & & & & & & & & girls \\
\hline & & $(2)$ & (3) & (1) & $(2)$ & (3) & (1) & (2) & (3) \\
\hline Recognized madrasah & $\begin{array}{c}0.231 \\
(4.83)^{* *}\end{array}$ & $\begin{array}{c}0.19 \\
(3.83)^{* *}\end{array}$ & $\begin{array}{l}0.051 \\
(0.43)\end{array}$ & $\begin{array}{l}0.052 \\
(1.13)\end{array}$ & $\begin{array}{c}-0.004 \\
(0.08)\end{array}$ & $\begin{array}{c}-0.042 \\
(0.36)\end{array}$ & $\begin{array}{c}0.211 \\
(4.67) * *\end{array}$ & $\begin{array}{c}0.167 \\
(3.58)^{* *}\end{array}$ & $\begin{array}{l}-0.163 \\
(1.44)\end{array}$ \\
\hline Unrecognized madrasah & $\begin{array}{c}0.501 \\
(8.12)^{* *}\end{array}$ & $\begin{array}{c}0.485 \\
(5.75)^{* *}\end{array}$ & $\begin{array}{c}0.288 \\
(167)+\end{array}$ & $\begin{array}{c}0.444 \\
(7.41)^{* *}\end{array}$ & $\begin{array}{c}0.456 \\
\left(5.577^{* *}\right.\end{array}$ & $\begin{array}{c}0.425 \\
(252)^{*}\end{array}$ & $\begin{array}{c}0.801 \\
(1322)^{* *}\end{array}$ & 0.693 & 0.259 \\
\hline Proportion of female teachers & & & $\begin{array}{l}0.318 \\
(1.35)\end{array}$ & & & $\begin{array}{l}0.359 \\
(1.54)\end{array}$ & & & $\begin{array}{l}-0.298 \\
(1.32)\end{array}$ \\
\hline Mean teacher experience & & & $\begin{array}{l}0.005 \\
(1.18)\end{array}$ & & & $\begin{array}{c}0.011 \\
(2.51)^{*}\end{array}$ & & & $\begin{array}{c}0.017 \\
(3.91)^{* *}\end{array}$ \\
\hline Proportion of trained teachers & & & $\begin{array}{l}0.111 \\
(1.32)\end{array}$ & & & $\begin{array}{l}0.086 \\
(1.05)\end{array}$ & & & $\begin{array}{l}-0.159 \\
(1.99)^{*}\end{array}$ \\
\hline Proportion of teachers with religious education & & & $\begin{array}{c}0.554 \\
(2.35)^{*}\end{array}$ & & & $\begin{array}{c}0.438 \\
(1.90)^{+}\end{array}$ & & & $\begin{array}{c}0.663 \\
(2.96)^{* *}\end{array}$ \\
\hline Proportion of non-Muslim teachers & & & $\begin{array}{l}0.146 \\
(0.84)\end{array}$ & & & $\begin{array}{c}0.408 \\
(2.36)^{*}\end{array}$ & & & $\begin{array}{c}0.282 \\
(1.69)^{+}\end{array}$ \\
\hline Mean family size of teachers & & & $\begin{array}{c}-0.036 \\
(2.75)^{* *} \\
\end{array}$ & & & $\begin{array}{c}-0.06 \\
(4.71)^{* *}\end{array}$ & & & $\begin{array}{r}-0.012 \\
(0.93) \\
\end{array}$ \\
\hline Family background controls? & no & yes & yes & no & yes & yes & no & yes & yes \\
\hline $\mathrm{N}$ & 3441 & 3441 & 3441 & 3435 & 3435 & 3435 & 3427 & 3427 & 3427 \\
\hline Pseudo $\mathrm{R}^{2}$ & 0.01 & 0.02 & 0.02 & 0.01 & 0.02 & 0.03 & 0.02 & 0.03 & 0.03 \\
\hline \multicolumn{10}{|l|}{ FEMALE } \\
\hline Recognized madrasah & $\begin{array}{c}0.241 \\
(7.28)^{* *}\end{array}$ & $\begin{array}{c}0.237 \\
(6.87)^{* *}\end{array}$ & $\begin{array}{c}0.02 \\
(0.22)\end{array}$ & $\begin{array}{c}0.194 \\
(5.79)^{* *}\end{array}$ & $\begin{array}{c}0.169 \\
(4.84)^{* *}\end{array}$ & $\begin{array}{l}-0.113 \\
(1.22)\end{array}$ & $\begin{array}{c}0.292 \\
(8.87)^{* *}\end{array}$ & $\begin{array}{c}0.262 \\
(7.65)^{* *}\end{array}$ & $\begin{array}{c}0.169 \\
(1.87)^{+}\end{array}$ \\
\hline Unrecognized madrasah & $\begin{array}{c}0.783 \\
(8.30)^{* *}\end{array}$ & $\begin{array}{c}0.607 \\
(6.08)^{* *}\end{array}$ & $\begin{array}{c}0.408 \\
(2.61)^{* *}\end{array}$ & $\begin{array}{c}0.943 \\
(9.42)^{* *}\end{array}$ & $\begin{array}{c}0.72 \\
(6.82)^{* *}\end{array}$ & $\begin{array}{c}0.329 \\
(2.04)^{*}\end{array}$ & $\begin{array}{c}0.962 \\
(10.48)^{* *}\end{array}$ & $\begin{array}{c}0.667 \\
(6.85) * *\end{array}$ & $\begin{array}{c}0.605 \\
(3.93)^{* *}\end{array}$ \\
\hline Proportion of female teachers & & & $\begin{array}{l}-0.241 \\
(1.96)^{*}\end{array}$ & & & $\begin{array}{l}0.007 \\
(0.05)\end{array}$ & & & $\begin{array}{l}-0.151 \\
(1.24)\end{array}$ \\
\hline Mean teacher experience & & & -0.011 & & & $\begin{array}{l}-0.006 \\
(153)\end{array}$ & & & $\begin{array}{l}-0.008 \\
(2.25)^{*}\end{array}$ \\
\hline Proportion of trained teachers & & & $\begin{array}{c}-0.228 \\
(3.16)^{* *}\end{array}$ & & & $\begin{array}{l}-0.014 \\
(0.19)\end{array}$ & & & $\begin{array}{c}-0.26 \\
(3.64)^{* *}\end{array}$ \\
\hline Proportion of teachers with religious education & & & $\begin{array}{l}0.206 \\
(1.16)\end{array}$ & & & $\begin{array}{c}0.67 \\
(3.71)^{* *}\end{array}$ & & & $\begin{array}{r}-0.143 \\
(0.82)\end{array}$ \\
\hline Proportion of non-Muslim teachers & & & $\begin{array}{l}0.086 \\
(0.66)\end{array}$ & & & $\begin{array}{c}0.226 \\
(1.69)^{+}\end{array}$ & & & $\begin{array}{r}-0.129 \\
(0.98)\end{array}$ \\
\hline Mean family size of teachers & & & $\begin{array}{c}0.082 \\
(7.78)^{* *}\end{array}$ & & & $\begin{array}{c}0.041 \\
(3.89)^{* *}\end{array}$ & & & $\begin{array}{c}0.036 \\
(3.48)^{* *}\end{array}$ \\
\hline Family background controls? & no & yes & yes & no & yes & yes & no & yes & Yes \\
\hline getate & 5010 & 5010 & 5010 & 4999 & 4999 & 4999 & 4981 & 4981 & 4981 \\
\hline Pseudo R ${ }^{2}$ & 0.01 & 0.04 & 0.04 & 0.01 & 0.05 & 0.05 & 0.01 & 0.04 & 0.04 \\
\hline
\end{tabular}


Table 4: School "fixed effects" estimates of determinants of gender attitudes

\begin{tabular}{|c|c|c|c|c|c|c|}
\hline & \multicolumn{2}{|c|}{$\begin{array}{l}\text { Boys more intelligent } \\
\text { than girls }\end{array}$} & \multicolumn{2}{|c|}{$\begin{array}{c}\text { Men better political leaders } \\
\text { than women }\end{array}$} & \multicolumn{2}{|c|}{$\begin{array}{l}\text { Higher education more important } \\
\text { for boys than girls }\end{array}$} \\
\hline & $(1)$ & $(2)$ & $(1)$ & $(2)$ & $(1)$ & $(2)$ \\
\hline \multicolumn{7}{|l|}{ Primary school type attended } \\
\hline \multirow[t]{2}{*}{ Recognized madrasah } & 0.059 & 0.055 & 0.04 & 0.041 & -0.013 & -0.006 \\
\hline & $(1.01)$ & $(0.94)$ & $(0.76)$ & $(0.77)$ & $(0.22)$ & $(0.09)$ \\
\hline \multirow[t]{2}{*}{ Unrecognized madrasah } & 0.122 & 0.114 & -0.002 & -0.002 & 0.122 & 0.117 \\
\hline & $(1.97)^{*}$ & $(1.82)+$ & $(0.03)$ & $(0.03)$ & $(1.91)^{+}$ & $(1.80)^{+}$ \\
\hline \multicolumn{7}{|l|}{ Child characteristics } \\
\hline \multirow[t]{2}{*}{ Female } & -0.858 & -0.835 & -0.536 & -0.517 & -0.872 & -0.863 \\
\hline & $(29.39)^{* *}$ & $(28.20)^{* *}$ & $(20.17)^{* *}$ & $(19.14)^{* *}$ & $(28.99)^{* *}$ & $(28.18)^{* *}$ \\
\hline \multirow[t]{2}{*}{ Child age } & & -0.029 & & 0.137 & & 0.145 \\
\hline & & $(0.29)$ & & $(1.48)$ & & $(1.37)$ \\
\hline \multirow[t]{2}{*}{ Child age, squared } & & 0.001 & & -0.005 & & -0.005 \\
\hline & & $(0.29)$ & & $(1.51)$ & & $(1.28)$ \\
\hline \multirow[t]{2}{*}{ Student upset } & & 0.07 & & 0.01 & & 0.10 \\
\hline & & $(2.47)^{* *}$ & & $(0.07)$ & & $(3.07)^{* *}$ \\
\hline \multicolumn{7}{|l|}{ Family background } \\
\hline \multirow[t]{2}{*}{ Mother's edu: grade 5 completed } & & -0.02 & & -0.014 & & -0.016 \\
\hline & & $(0.54)$ & & $(0.41)$ & & $(0.43)$ \\
\hline \multirow[t]{2}{*}{ Mother's edu: grades 6-9 completed } & & -0.047 & & -0.002 & & -0.115 \\
\hline & & $(1.19)$ & & $(0.05)$ & & $(2.84)^{* *}$ \\
\hline \multirow[t]{2}{*}{ Mother's edu: grades 10 completed } & & 0.013 & & 0.004 & & -0.031 \\
\hline & & $(0.28)$ & & $(0.11)$ & & $(0.68)$ \\
\hline \multirow[t]{2}{*}{ Mother's edu: grade $10+$ completed } & & -0.062 & & 0.058 & & 0.011 \\
\hline & & $(1.04)$ & & $(1.08)$ & & $(0.19)$ \\
\hline \multirow[t]{2}{*}{ Father's edu: grade 5 completed } & & -0.022 & & -0.006 & & -0.047 \\
\hline & & $(0.59)$ & & $(0.15)$ & & $(1.03)$ \\
\hline \multirow[t]{2}{*}{ Father's edu: grades 69 completed } & & -0.088 & & -0.031 & & -0.075 \\
\hline & & $(2.27)^{*}$ & & $(0.88)$ & & $(1.88)+$ \\
\hline \multirow[t]{2}{*}{ Father's edu: grades 10 completed } & & -0.057 & & -0.029 & & 0.015 \\
\hline & & $(1.42)$ & & $(0.78)$ & & $(0.36)$ \\
\hline \multirow[t]{2}{*}{ Father's edu: grade $10+$ completed } & & -0.156 & & -0.125 & & -0.141 \\
\hline & & $(3.72)^{* *}$ & & $(3.29)^{* *}$ & & $(3.25)^{* *}$ \\
\hline \multirow[t]{2}{*}{ Newspaper-magazine at home } & & 0.009 & & -0.088 & & -0.048 \\
\hline & & $(0.29)$ & & $(3.12)^{* *}$ & & $(1.51)$ \\
\hline \multirow[t]{2}{*}{ Asset index } & & -0.008 & & 0.016 & & -0.019 \\
\hline & & $(0.54)$ & & (1.21) & & $(1.21)$ \\
\hline \multirow[t]{2}{*}{ Constant } & 4.209 & 4.473 & 4.229 & 3.323 & 3.809 & 2.79 \\
\hline & $(189.86)^{* *}$ & $(6.03)^{* *}$ & $(209.47)^{* *}$ & $(4.91)^{* *}$ & $(166.64)^{* *}$ & $(3.64)^{* *}$ \\
\hline $\mathrm{N}$ & 8604 & 8451 & 8585 & 8434 & 8559 & 8408 \\
\hline $\mathrm{R}^{2}$ & 0.10 & 0.10 & 0.05 & 0.05 & 0.09 & 0.10 \\
\hline
\end{tabular}

Note: (a) Estimates are based on OLS regression which includes 400 school/madrasah dummies. (b) Coefficient jumps to 0.22 (from 0.12) as we drop the female dummy in the first and third regressions. (c) The estimated coefficient on primary standard madrasahs capture sub-sample of children who have switched from madrasah to school stream (or one madrasah type to another one and so on). 


\section{Endnotes}

i Specific cases of such alliance with faith leaders to promote modern contraception is well-documented for Jordan (Underwood and Kamhawi, 2014), Afghanistan (Huber et al. 2010), Indonesia (Warwick, 1986), Bangladesh (Simmons et al., 1988), Tunisia (Obermeyer, 1994) and Nigeria (Orubuloye 1993).

ii Using multivariate statistical analysis, Authors (2009) find that as a consequence of the feminization process, Bangladeshi regions that had a larger stock of madrasahs experienced higher rate of growth in female enrolment following introduction of the female stipend scheme.

iii However even textbooks used by secondary (non-madrasah) schools may lack representation of women and girls. According to one study on Pakistan, women received no mention in 20 out of 22 lessons in one English textbook (Shah, 2012).

iv Parents may still value such restrictions in rural areas for practical reasons. For instance, there is evidence that the practice of purdah by madrasahs help increase secondary education participation in communities with restrictions on outside mobility of girls (Authors 2012).

vThis is similar to social settings in ultra-Orthodox Communities (Berman 2000).

vi The program also helped develop a book entitled "Family Planning in the Light of Islam" which provides Imams with important information about reproductive health that are consistent with the principles of hadiths and the holy Quran. Imams (Muslim religious leaders who lead prayers in mosque and are mostly Qawmi madrasah schooled) were informed about family planning in the cultural and religious context of Islam. Family planning messages were spread to mosque goers during Friday prayer sermons relying on the nationwide network of Imams.

vii This finding is consistent with an earlier study of attitudinal differences across Islamic and non-religious schools in Bangladesh (see Authors, 2010). However, the study is incomplete in two respects. First, the authors have not studied male graduates whose attitudes matter most in a patriarchal society. The analysis relies on a small sample of female graduates of recognized secondary schools and madrasahs. Consequently, we do not know whether the attitudinal gap by gender varies by religious and non-religious education. Second, Authors (2010) have not studied graduates of unrecognized madrasahs.

viii Such controls for socio-socio-demographic characteristics are common in studies on the determinant of adolescent attitude and behaviour (see for instance Donahue and Benson, 1995). Given the cost differences, it is also possible that parents send children with lower (perceived) abilities to madrasahs. However, administrative data on sample (non-religious) schools and madrasahs indicate that majority secondary educational institutions do not have an admission test. If anything, 66\% sample unrecognized madrasahs have an admission test compared to only 33\% sample (non-religious) schools. Sample (non-religious) schools and unrecognized madrasahs also do not differ in terms of restrictions on the admission of physically challenged students. Only in one respect, (non-religious) schools and madrasahs differ in admission policy. Both types of madrasahs confirm religion-specific sorting whereby admission is largely reserved for Muslim children. However, in our data, there is no systematic gap in gender attitudes across Muslim and non-Muslim students; see Table 1. In sum, a higher proportion of madrasahs (regulated or not) report having an admission test indicating greater selectivity compared to (non-religious) schools.

${ }^{\text {ix }}$ We do not use purdah related indicators as control variables since all traditional madrasahs use Burqa as a dress code and have purdah policy for girls in and out of madrasah.

$\mathrm{x}$ There is an economics literature on the intergenerational transmission of cultural traits which explains acquisition of preferences of children through an adaptation and imitation process which depends on their parents' socialization actions, and on the cultural and social environment in which children live (see e.g. Bisin and Verdier, 2001; Loehlin, 2005).

${ }^{x i}$ Asadullah et al. develop a two-period model that explains madrasah choice in terms of economic and noneconomic considerations. Children are described as a source of old age transfers, where the amount of transfers is determined by the labour market outcome of the children as well as their religious values. At the same time, non-economic factors such as parent's personal beliefs play a role - religious parents draw satisfaction by sending a proportion of their children to madrasahs regardless of the economic gains from such choice. The model predicts higher madrasah enrolment in households that are poorer and more religious.

xii The observed gender attitudes could be equally a reflection of social norms regarding girls' future role as a married woman. Upon marriage, parents expect their daughter to work in her husband's home and take care of household chores. More progressive parents therefore may opt for secular school education to prepare girls for work outside the household.

xiii There is growing evidence teachers vary in terms of their attitudes to gender and this can affect learning outcomes. In Turkey, a one-term pre-service course on gender equity had a significant impact on female teachers’ gender attitudes and awareness (UNESCO 2014).

${ }^{\mathrm{xiv}}$ Guiso et al (2003) found that religious people tend to be less favorable with respect to working women. 


\footnotetext{
${ }^{x v}$ An exception is the importance of higher education. However, even here the coefficient size is reduced by 50 per cent once detailed controls are included (see model 1 vs. 3).

xvi It is noteworthy that female teachers exert no influence on student attitudes. This could be explained by the fact that female teachers are rare and likely to have limited voice within madrasahs where the main authority lies with male teachers (Jeffrey et al 2012). Female teachers rarely assume leadership role in secondary madrasahs where the head teacher is almost always a male.

xvii $23 \%$ of unrecognized madrasa sample students are girls.

xviii In their analysis of fertility transition in rural Bangladesh, Munshi and Myaux (2006) noted that individual contraception choice of decision responded strongly to changes in the norm in one's own religious group within the same village. A similar mechanism may explain the differences in family size among teachers. It's also possible that behavior, attitudes, and choices of Qawmi teachers are constrained by outcomes of others from the Qawmi networks. Anecdotal evidence indicates limited social interactions between Qawmi leaders and others. xix This approach accounts for all factors that are specific to the secondary school/madrasa the student is currently enrolled in.

${ }^{x x}$ There is an economics literature on the intergenerational transmission of cultural traits which explains acquisition of preferences of children through an adaptation and imitation process which depends on their parents' socialization actions, and on the cultural and social environment in which children live (see e.g. Bisin and Verdier, 2001; Loehlin, 2005).

xxi In the new textbook for grade one, for instance, the letter ' $O$ ' is used to describe 'orna', a type of scarf worn by religious Muslim girls, instead of 'ol', a type of yam (Ahmed 2017).
} 


\section{Appendix A. Data sources, definitions and descriptive statistics}

The QSSMEB survey covered both on secondary teachers and students in rural Bangladesh. The primary objective of the survey was to address the quality of education in public-aided secondary schools and madrasahs. We randomly selected 48 Unions from 12 districts (World Bank 2010). We surveyed all secondary educational institutions in each sample Union, ${ }^{i}$ which gathered detailed information on all teachers and students of grade 8 . All head teachers were interviewed about dress code and classroom organization of students as well as physical facilities at schools. The enumerators also collected self-reported household information from tested children enrolled in grade 8. Most importantly, socio-economic attitudes of pupils and teachers were collected using a set of questions adopted from the World Values Survey $(\mathrm{WVS})^{\mathrm{ii}}$. In total, data on 403 secondary educational institutions were collected. To our knowledge, this is the largest quantitative survey that provides nationally spread out data on Islamic schools in Bangladesh.

The QSSMEB data is ideal for our purpose as it covered non-religious secondary schools as well as recognized and unrecognized madrasahs -- 35\% of our sample respondents report being in madrasahs (27\% in recognized and $8 \%$ in traditional) and $65 \%$ of recognized madrasah students are girls against $24 \%$ in traditional madarsahs. Seventy-four per cent of our sampled unrecognized madrasahs is all male while only $9.5 \%$ are coeducational ${ }^{\mathrm{iii}}$. In contrast, $80 \%$ of our sampled recognized madrasahs is coeducational. Similarly, $83 \%$ of our sample schools is coeducational. This composition of our sample presents a unique institutional setting where students are exposed to three different educational regimes that differ in terms of intensity of religious education, teacher background as well as gendernorms in schools.

Table A1: Summary statistics

\begin{tabular}{|c|c|c|c|c|c|c|c|c|}
\hline \multirow{3}{*}{ Variables } & \multicolumn{2}{|c|}{ All students } & \multicolumn{2}{|c|}{ Non-madrasah sample } & \multicolumn{4}{|c|}{ Madrasah sample } \\
\hline & \multirow[b]{2}{*}{ Mean } & \multirow[b]{2}{*}{ Std. Dev. } & \multirow[b]{2}{*}{ Mean } & \multirow[b]{2}{*}{ Std. Dev. } & \multicolumn{2}{|c|}{ Recognized } & \multicolumn{2}{|c|}{ Traditional } \\
\hline & & & & & Mean & Std. Dev. & Mean & Std. Dev. \\
\hline \multicolumn{9}{|l|}{ School type attended } \\
\hline Recognized secondary madrasah & 0.27 & 0.44 & & & & & & \\
\hline Unrecognized secondary madrasah & 0.08 & 0.27 & & & & & & \\
\hline \multicolumn{9}{|l|}{ Child attributes } \\
\hline Child age & 13.35 & 1.42 & 13.05 & 0.96 & 13.35 & 1.16 & 15.94 & 2.50 \\
\hline Female & 0.59 & 0.49 & 0.61 & 0.49 & 0.65 & 0.48 & 0.24 & 0.43 \\
\hline Student upset & 0.24 & 0.43 & 0.25 & 0.43 & 0.23 & 0.42 & 0.25 & 0.43 \\
\hline \multicolumn{9}{|l|}{ Family background } \\
\hline Mother's edu: grade 5 completed & 0.19 & 0.39 & 0.19 & 0.39 & 0.20 & 0.40 & 0.17 & 0.38 \\
\hline Mother's edu: grades 6-9 completed & 0.17 & 0.37 & 0.17 & 0.37 & 0.17 & 0.37 & 0.17 & 0.37 \\
\hline Mother's edu: grades 10 completed & 0.13 & 0.33 & 0.13 & 0.34 & 0.12 & 0.32 & 0.09 & 0.29 \\
\hline Mother's edu: grade $10+$ completed & 0.06 & 0.24 & 0.07 & 0.26 & 0.04 & 0.19 & 0.04 & 0.19 \\
\hline Father's edu: grade 5 completed & 0.12 & 0.32 & 0.12 & 0.32 & 0.13 & 0.33 & 0.09 & 0.29 \\
\hline Father's edu: grades 6-9 completed & 0.17 & 0.37 & 0.17 & 0.38 & 0.17 & 0.37 & 0.18 & 0.38 \\
\hline Father's edu: grades 10 completed & 0.16 & 0.36 & 0.16 & 0.36 & 0.16 & 0.37 & 0.14 & 0.35 \\
\hline Father's edu: grade $10+$ completed & 0.18 & 0.38 & 0.19 & 0.39 & 0.14 & 0.35 & 0.21 & 0.41 \\
\hline Newspaper-magazine at home & 0.39 & 0.49 & 0.39 & 0.49 & 0.33 & 0.47 & 0.54 & 0.50 \\
\hline Asset index & 0.01 & 1.00 & 0.10 & 1.02 & -0.13 & 0.94 & -0.30 & 0.88 \\
\hline \multicolumn{9}{|l|}{ Teacher characteristics } \\
\hline Proportion of female teachers & 0.15 & 0.14 & 0.18 & 0.12 & 0.09 & 0.12 & 0.11 & 0.23 \\
\hline Mean teacher experience & 13.90 & 5.23 & 14.48 & 4.94 & 12.89 & 5.23 & 12.53 & 6.63 \\
\hline Proportion of trained teachers & 0.54 & 0.32 & 0.70 & 0.25 & 0.25 & 0.18 & 0.21 & 0.32 \\
\hline Proportion of teachers with religious education & 0.25 & 0.26 & 0.08 & 0.05 & 0.52 & 0.13 & 0.73 & 0.17 \\
\hline Proportion of non-Muslim teachers & 0.12 & 0.15 & 0.18 & 0.16 & 0.01 & 0.04 & 0.00 & 0.04 \\
\hline Mean family size & 1.97 & 1.59 & 1.98 & 1.49 & 1.81 & 1.68 & 2.45 & 2.02 \\
\hline District & & & & & & & & \\
\hline
\end{tabular}




\begin{tabular}{|c|c|c|c|c|c|c|c|c|}
\hline Barisal & 0.08 & 0.27 & 0.07 & 0.26 & 0.08 & 0.28 & 0.14 & 0.34 \\
\hline Bogra & 0.07 & 0.26 & 0.07 & 0.26 & 0.07 & 0.25 & 0.08 & 0.27 \\
\hline Chandpur & 0.11 & 0.31 & 0.11 & 0.32 & 0.12 & 0.32 & 0.01 & 0.10 \\
\hline Chittagong & 0.08 & 0.27 & 0.06 & 0.24 & 0.07 & 0.26 & 0.26 & 0.44 \\
\hline Comilla & 0.15 & 0.36 & 0.17 & 0.38 & 0.13 & 0.33 & 0.08 & 0.27 \\
\hline Faridpur & 0.07 & 0.25 & 0.07 & 0.25 & 0.06 & 0.25 & 0.08 & 0.27 \\
\hline Jessore & 0.12 & 0.32 & 0.13 & 0.33 & 0.11 & 0.32 & 0.04 & 0.20 \\
\hline Kurigram & 0.06 & 0.24 & 0.06 & 0.24 & 0.08 & 0.27 & 0.02 & 0.15 \\
\hline Laksmipur & 0.11 & 0.31 & 0.11 & 0.31 & 0.11 & 0.31 & 0.05 & 0.22 \\
\hline Mymensing & 0.06 & 0.24 & 0.06 & 0.23 & 0.07 & 0.25 & 0.08 & 0.27 \\
\hline $\mathrm{N}$ & 8604 & & 5642 & & 2305 & & 657 & \\
\hline
\end{tabular}

Table A1 presents the summary statistics based on the working sample that we use for our main empirical analysis. Since we are interested in attitudes towards gender equality, it is also important to understand the gender orientation of the institutional environment across secondary schools and madrasahs. A hallmark of madrasahs in Bangladesh and elsewhere is the visible focus on religious symbolism. These Islamic schools implement strict dress codes along an orthodox Islamic style and impose restrictions on female mobility in and outside school.

Table A2: Gender norms in dress codes by school type

\begin{tabular}{lccccc}
\hline & \multicolumn{5}{c}{ Female Dress } \\
\cline { 2 - 6 } & $\begin{array}{c}\text { No dress } \\
\text { code }\end{array}$ & $\begin{array}{c}\text { Salwar \& } \\
\text { kameez }\end{array}$ & $\begin{array}{c}\text { Head cover } \\
\text { only }\end{array}$ & Niqab & Burqa \\
\cline { 2 - 6 } Non-religious schools (N=199) & 0.11 & 0.87 & 0.38 & 0.04 & 0.01 \\
Recognized madrasah (N=123) & 0.15 & 0.30 & 0.35 & 0.13 & 0.69 \\
Unrecognized madrasah (N=19) & 0.00 & 0.32 & 0.32 & 0.21 & 1.00 \\
\cline { 2 - 6 } & \multicolumn{7}{c}{ Male Dress Code } & Trouser \\
\cline { 2 - 6 } & No dress & Turban/ & Panjabi/ & Pajama/ & \& shirt \\
non-religious schools (N=175) & 0.11 & 0.02 & 0.00 & 0.00 & 0.89 \\
Recognized madrasah (N=103) & 0.29 & 0.57 & 0.80 & 0.29 & 0.02 \\
Unrecognized madrasah (N=72) & 0.11 & 0.63 & 0.82 & 0.31 & 0.02 \\
\hline
\end{tabular}

Note: (a) 63 (62) are only girls (boys) schools; these are discarded when examining data on dress code for boys (girls). (b) Figures correspond to multiple responses to the question: "Is there any uniform for boy (girl) students of this school/madrasah?” and hence row figures don't add up to 1. (c) Salwar and kameez refers to a type of suit, typically worn by South Asian women, with loose trousers and a long shirt. Niqab is a piece of cloth covering the whole face except the eyes. Burqa is a long, loose robe covering the whole body from head to feet. (d) Turban refers to head covering for men while Topi is a religious cap. (e) Panjabi, also known as kurta in India and Pakistan, is a collarless long shirt while Alkhalla is worn as a long frock extending to below the knees. Both are popular upper garments for Muslim men. Lungi is lower garment for men, worn as a skirt in Bangladesh and neighboring West Bengal province of India.

Table A2 reports data on female dress-codes in sample schools. First note that there is not a single unrecognized madrasah (out of 19 coeducational or girls-only) without a dress code on female students. On the other hand, their recognized counterparts appear to practice a slightly more liberal regime - $15 \%$ of them do not have any official dress code for their female students. The same pattern prevails when we look at the nature of the required attire female students are officially expected to wear. In all unrecognized madrasahs, girls are required to wear Burqa (compared to 69\% of recognized madrasahs). Similarly, the incidence of Niqab is most common in unrecognised madrasahs: $21 \%$ of these madrasahs implement this as a dress code compared to only $10 \%$ recognized madrasahs. However, when compared to boys, girls are subject to much stricter dress code (see Table A2). First, 29\% of recognized 
madrasahs do not have any official dress code for male students. Second, in $82 \%$ unrecognized madrasahs, boys are required to wear 'Panjabi' (long Islamic dress covering full body) compared to the requirement of Burqa for girls in all unrecognized madrasahs.

We additionally asked head teachers to comment on any official policies relating to the practice of 'purdah' inside the madrasah/school compound. 'Purdah' can range from strict segregation of the sexes to wearing a loose scarf around one's head when out in public. Once again, unrecognized madrasahs appear to strictly implement the policy of 'purdah' irrespective of whether it is outside or inside the classroom. But so do state-regulated madrasahs: $85 \%$ of recognized madrasahs require female students to practice 'purdah' inside the classroom compared to $95 \%$ of unrecognized students.

\footnotetext{
${ }^{\text {i }}$ There are 7 administrative divisions and 64 districts in total in Bangladesh with Dhaka being the capital district. Each district comprises of several sub-districts (also known as Upazilas) while each sub-district comprise of several Unions. In other words, Unions are the smallest rural administrative and local government units in the country. One Union usually contains 9-10 villages. It is noteworthy to mention that in the rare event when institutions attended by children were outside our original sample Union, we also covered those secondary schools and madrasas located in neighbouring Unions.

ii The QSSMEB study also included a household module. However, given our focus on matched teacher-student attitudinal data, we do not use the household survey data in this paper.

iii In all of our coeducational unrecognized madrasas, however, boys and girls had separate classroom.
} 